\title{
PHYSIOLOGICAL AND MORPHOLOGICAL FEATURES DETERMINING THE PERFORMANCE OF THE SORGHUM LANDRACES OF NORTHERN NIGERIA
}

\author{
By I). J. FLOWER $\dagger$ \\ West African Sorghum Improvement Program, Internaliomal Cirops Research \\ Institute for the Semi-Arid Tropics (ICKISAT), +19 Yanvane' Aremue, Kuno. \\ Nigeria
}

(Accepled 8.June 199.5)

SUMMARY

\begin{abstract}
Sorghum landraces from contrasting districts of northern Nigeria were grown during lhe ly99() rainy season to describe their phỵsiolegical and morphological leatures. (iloanges in their dry matter production and yicld could be predicted from thermal time lo flowering (basted on response to a fixed daylength) and partitioning indices. Many ofher morpholongical and

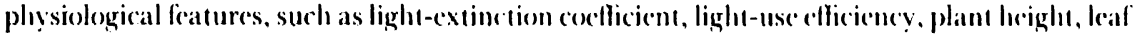
area and leal number, were either stable or varied systematically wilh time fo flewering. (iratin yields of carly maturing lines were limited by low light interception from flowering (o) plyysiological maturity and those of latcr maturing lines by highly silc-specilic droughto stress.
\end{abstract}

\section{INTRODUG:TION}

In northern Nigeria, rainfall and length of the rainy season decrease as latitude increases (Kowal and Knabe, 1973). Thus, Kano $\left(12^{\circ} 03^{\prime} \mathrm{N}, 08^{\circ} 32^{\prime} \mathrm{E}\right)$ reccives an annual rainfall of $830 \mathrm{~mm}$ while the nearby town of $\mathrm{Nguru}\left(12^{\circ} 53^{\prime} \mathrm{N}, 10^{\circ} 28^{\prime} \mathrm{E}\right)$ receives only $566 \mathrm{~mm}$. There are also pronounced year-to-year differences in the onset of the growing season and the total amount of rainfall received. In Kano, for example, rainfall ranges from 230 to $1200 \mathrm{~mm}$. This spatial and temporal variability in the climate creates major problems for researchers trying to match cultivars with their best environments and to breed new 'adapted' cultivars.

Sorghum is grown on an area of 480 million hectares in Nigeria but average yields are only $1.07 \mathrm{t} \mathrm{ha}^{-1}$ (FAO, 1993). It is grown throughout the country, but sorghum-based cropping systems predominate between the maize-based systems south of Zaria $\left(11^{\circ} 11^{\prime} \mathrm{N}, 07^{\circ} 38^{\prime} \mathrm{E}\right)$ and the millet-based systems north of Katsina $\left(13^{\circ} 01^{\prime} \mathrm{N}, 07^{\circ} 41^{\prime} \mathrm{E}\right)$. Sorghum-based cropping systems mostly use photoperiodsensitive sorghum which flowers after the end of the rains at each location (Curtis, 1968), thus avoiding the mould that often renders the grain unfit for human consumption. The grain is therefore produced under conditions of a deteriorating soil water balance. $A$ n early cessation in rainfall causes terminal drought stress resulting in little grain being harvested.

†Present address: Agronomy Division, ICRISAT Asia Center, Patancheru, Andhra Pradesh, 502324, India. 
Nlthough plant breeders have introduced new varieties and hybrids, few farmers have adopted them, preferring the local landraces (Carr, 1989). SubSaharan $\Lambda$ frica is a primary centre of origin and diversity of sorghum (Mengesha et al., 1991) so that a vast array of landraces can be found in farmers' fields in northern Nigeria. Staff of the International Crops Research Institute for the Semi$\Lambda$ rid Tropics (ICRISAT) have collected a wide range of material from this area and described 230 accessions belonging to the races Durra-Caudatum, GuineaCaudatum and Guinea-Guineense (Prasada Rao el al., 1985; see also Curtis, 1967). From this material the Kano State Agricultural and Rural Development $\Lambda$ uthority has identified a sub-set of 36 landraces that have agricultural potential in the region (KNARI)A, 1986). 'These vary markedly in time to flower, leaf number, height, grain colour, grain type and yield of grain and stover.

$\Lambda$ study of this material was conducted in order to understand the basis of the continued preference by farmers for local landraces and to describe the morphological and physiological features that influence the performance of landraces in the region. The interactions of these features with the environment were then summarized by a simple, biologically relevant model. This provides a basis for designing efficient production systems and for understanding the interaction of traditional systems with their environment.

\section{EXPERIMENTAI. DETAILS}

The 36 sorghum (Sorghum bicolor (L.) Moench) landraces were planted at the ICIRIS $\Lambda \mathrm{T}$ research station at Bagauda $\left(11^{\circ} 53^{\prime} \mathrm{N}, 08^{\circ} 14^{\prime} \mathrm{E}\right)$ in northern Nigeria, commencing on 7 July 1990 after a delayed start to the rainy scason. The soil type at Bagauda is a Plinthic Luvisol (FAO/UNESCO) with an average depth of 90 $\mathrm{cm}$. Measurements with a pressure-plate apparatus on undisturbed soil samples showed that its water holding capacity to $90 \mathrm{~cm}$ was $151 \mathrm{~mm}$ (IAR, 1988).

The landraces were planted in $4 \mathrm{~m}^{2}$ plots in a randomized block design with four replications. Sceds were hand sown on $75 \mathrm{~cm}$ ridges and thinned 20 days after sowing (I)SS) to a population of 8 plants $\mathrm{m}^{-2}$. Plots received a basal dressing of $15 \mathrm{~kg} \mathrm{ha}^{-1}$ nitrogen, $87 \mathrm{~kg} \mathrm{ha}^{-1}$ phosphorus $\left(\mathrm{P}_{2} \mathrm{O}_{5}\right)$ and $15 \mathrm{~kg} \mathrm{ha}^{-1}$ potassium, with a further top dressing, $24 \mathrm{DAS}$, of $46 \mathrm{~kg} \mathrm{ha}^{-1}$ nitrogen with urea. The experiment was rainfed and the plots were kept free of weeds. The sorghum was sprayed with Polytrin $C^{\circledR} 30 \mathrm{D} \Lambda \mathrm{S}$ for the control of leaf-feeding insects. No attempt was made to control head bugs (Eurystylus sp.) during the grain-filling period as damage was minimal.

Plant dry matter samples were taken on four plants per plot and dried in a convection oven at $60^{\circ} \mathrm{C}$. Leaf area was measured at flowering time with a leaf area meter (LI-COR, Nebraska, USA) and dry matter samples taken 41, 54 and $73 \mathrm{DAS}$ and at physiological maturity. The dry matter at flowering was measured on a sub-set of 13 lines. Grain yield was determined from measurements taken on $2 \mathrm{~m}^{2}$ plots using a mechanical thresher. Days to flowering were recorded when anthers werc extruded at the mid-point of the panicle and physiological maturity 
when a black layer appeared on grains located at the mid-point of the panicle. A plot was considered to have reached a particular stage when $50 \%$ of plants in the plot reached that stage. The length of the grain-filling period wats calculated as the time from flowering to maturity.

light interception was measured between 1100 and 1300) hours 41, 5.t and 73 DAS and at flowering with a Sunfleck Cieptometer (Decagen Devices lne., Washington, USA). Readings were taken, at ground level, to measure the amoumt of light transmitted, and adjacent to each plot to measure incident solatr radiation. Light interception, light-extinction coefficient and radiation-use cfliciency (RUE) were calculated using standard equations (Squire, 1990)).

Cilimatic variables were recorded on an adjacent automatic weather station (Campbell Scientific Inc., Utah, USA) ronsisting of a three-cup ancmometer (Met One Inc., Oregon, USA), silicon pyranometer (L.I-20)(s\%, L.I-(COR, Nebraska, USA) and temperature and humidity probes (Phy-(ihem Siciences Corp., New York, USA). The readings were made corery tive minutes, and hourly averages were stored. Potential coaporation estimates were obtained using the Penman equation (van Donk et al, 1988). The extractable water (in mm) at time 1 was cestimated as

$$
S_{(1)}=S_{(1)}+R_{(1)}-E_{(1)}
$$

where $S_{(0)}$ is the initial extractable soil water content, and $R_{(1)}$ and $E_{(1)}$ arre the rainfall and potential craporation $(\mathrm{mm})$, respectively, accumulated from $1=0$. When $S_{(1)}$ was less than $151 \mathrm{~mm}$, drainage and runofl were neglected because lhey were observed to be small fractions of the rainfall. When calculating the water budget, no attempt was made to partition Ep into its components, soil evaporation and crop transpiration, although changes in these variables aflece the difference between actual and potential rates of evaporation and hence the accuracy of the water budget. However, the canopy of many lines had clesed by early September and potential and actual evaporation would be similar from then on. Actual evaporation rates would be lower than potential rates when the canopy was small and the soil surface dry. However, the freguency of the rains was sued that this situation did not occur for extended periods carly in the season. When $S_{(1)}$ exceeded $1.51 \mathrm{~mm}$, excess water was assumed to be lost by drainage and runoff and when $S_{(1)}$ was less than $45 \mathrm{~mm}$ the evaporation rate was assumed $\left.t()\right)$ be $\left(S_{(1)}\right)$ 45) times the potential rate (Sinclair and Ludlow, 1986).

\section{$K N A R D A$ regional trials}

Details of the management of these trials are given by KNARI) $\Lambda$ (1986). Briefly, plants were grown according to recommended local practices. Seeds were sown by hand at a $50 \mathrm{~cm}$ row spacing with a density of $\overline{5}$ plants $\mathrm{m}^{-2}$. Trials were sown on the 16 June, 5 June, 23 June and 23 July 1986 at Kaffin Maiyaki, Kadawa, Katsina and Mallamadori, respectively. The dates of planting corresponded to the commencement of the rainy season, which was later at Katsina 


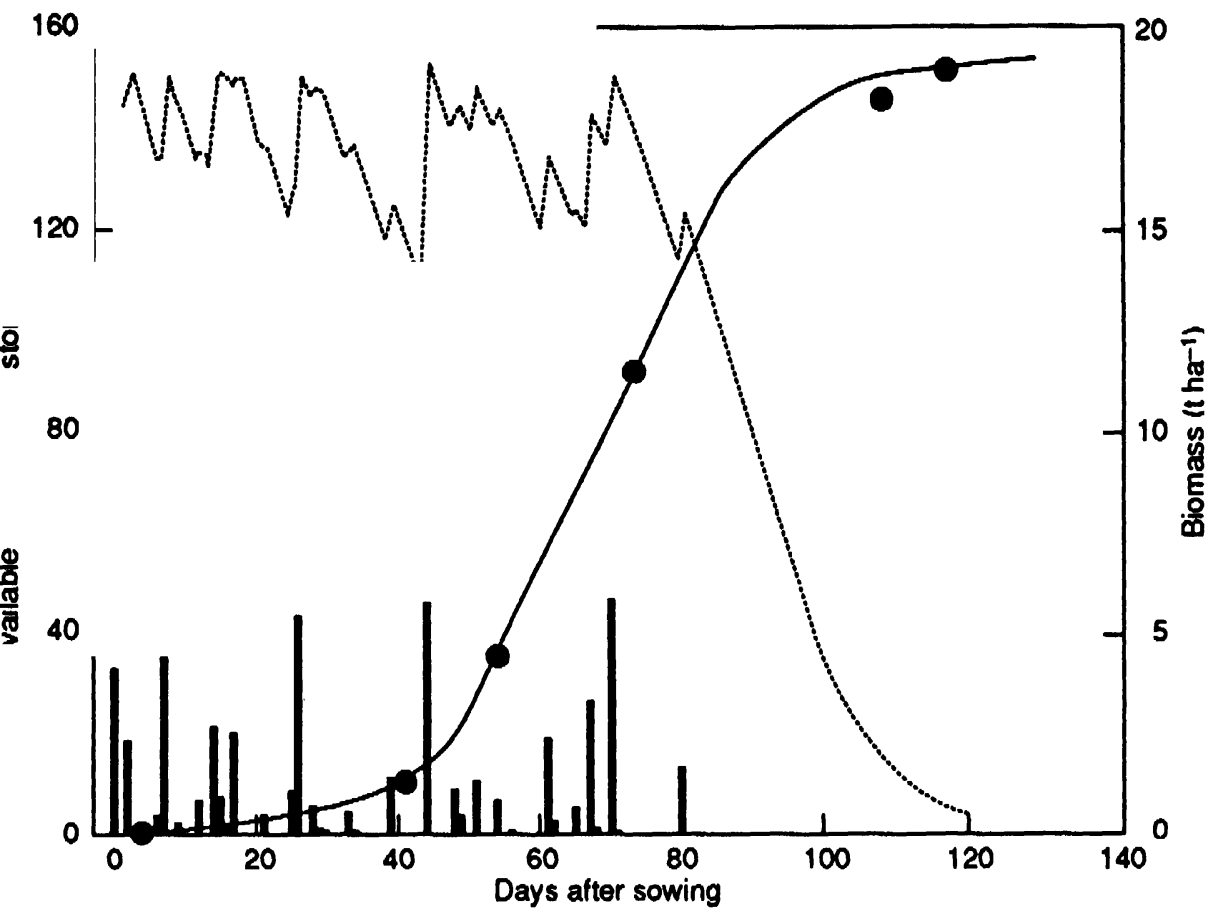

Fig. 1. Rainfall (solid bars), changes in extractable soil water content (dotted line) and dry matter production (solid circles) during 1990) at Bagauda, Nigeria. Data for dry matter production are the means for leng cluration linc's llowering 90 (o 100 days alter sowing; the solid line was fitted by cye.

and Mallamadori than at Kadawa and Kalfin Maiyaki. Fertilizer at the rate of 30 $\mathrm{kg} \mathrm{ha} \mathrm{a}^{-1}$ nitrogen, $30 \mathrm{~kg} \mathrm{ha}^{-1}$ phosphorus and $30 \mathrm{~kg} \mathrm{ha}^{-1}$ potassium was applied

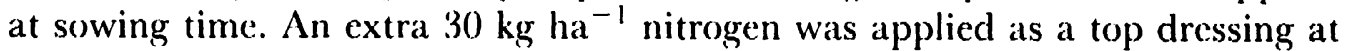
Katsina and Mallamadori. Grain yiclds were measured after threshing air-dried heads in the traditional manner. The area harvested for grain yicld was 90,90,150 and $7.5 \mathrm{~m}^{2}$ at Kaffin Maiyaki, Kadawa, Katsina and Mallamadori, respectively. Three replicate plots were grown at Kadawa and Mallamadori but only two at Kalfin Maiyaki and Katsina. To permit a valid comparison between sites only data from lines used in the Bagauda study were extracted from these regional trials.

\section{RESULTS AND DISCUSSION}

The mean minimum temperature at Bagauda was $21.9 \pm 0.2^{\circ} \mathrm{C}$ and the mean maximum $32.37 \pm 0.7^{\circ} \mathrm{C}$. The mean incident solar radiation was $20.5 \pm 0.3 \mathrm{MJ}$ $\mathrm{m}^{-2}$ day $^{-1}$. These conditions were conducive to the rapid growth of sorghum. Rainfall was well distributed (Fig. 1), although the total of $556 \mathrm{~mm}$ received was about $37 \%$ below the average annual rainfall for Kano (62 km north of Bagauda). Heavy rains of $72 \mathrm{~mm}$ between 11 and 14 September (67-70 DAS) relieved the 
potential threat of terminal drought. As a result the length of the growing season was not appreciably reduced.

The soil profile was near field capacity when the crop was sown. Due to the frequency of rainfall, soil moisture storage was above $110 \mathrm{~mm}$ for most of the season (Fig. 1). The rains had virtually ceased by $7(0) \mathrm{D} A \mathrm{~S}$ and the soil water reserves were being depleted. By day 105, the soil had little moisture left for crop growth.

\section{Dry matter production}

In northern Nigeria, there is only a limited period in which agricultural productivity can occur, so efficient use of soil water reserves is essential. Extrapolation of the linear region of the total above-ground dry weight/time relationship to the abscissa (Fig. 1) gives an estimate of "38 days "lost time" (Goudriaan and Monteith, 1990). As the growth of leaves up to the time of panicle initiation is similar in long and short duration lines, similar lost times can be expected in both. This is considerably longer than the 26.8 days measured for a sorghum crop grown at Hyderabad, India at a much higher density of 18.4 plants $\mathrm{m}^{-2}$ (Goudriaan and Monteith, 1990) and represents a substantial proportion of the time when the crop is productive in Kano. It also represents a period when soil evaporation and surface 'runoff' are major components of the water balance, causing appreciable inefficiency in the use of rainfall carly in the scason.

The dry weight/time relationship can be extrapolated forward to determine the time necessary to reach the maximum crop dry weight if maximum growth rates were to be maintained. After subtraction of lost time, a 'minimum productivity period' of 54 days was obtained for the 1990 rainy season at Bagauda. 'The lost time for a long duration sorghum crop growing at Bagauda is $4.5 \%$ of the minimum productivity period and $36 \%$ of that required for lines such as Gaya Early to mature. This percentage can be expected to increase when sorghum is grown at traditional densities of $10-20$ plants $\mathrm{m}^{-2}$ in an iniercrop, as the sorghum is sown before the intercropped groundnut or cowpea. The maximum growth rate, obtained when $90-95 \%$ of the light was being intercepted, was calculated at $20 \mathrm{~g} \mathrm{~m}^{-2}$ day $^{-1}$ (mean of long duration lines). This is similar to the values reported for sorghum grown under rainfed conditions in the semi-arid tropics in India (Goudriaan and Monteith, 1990) and in the humid sub-tropics of Australia (Herbert et al., 1986). Some $25 \%$ of the dry-matter production and more than $90 \%$ of the grain yicld from local landraces (such as Gaya Early) were produced under conditions of declining soil water status at Bagauda in 1990. These conditions occur in many years since the end of the rainy scason is relatively stable (Kowal and Knabe, 1973).

\section{Phenology}

Local landraces in neighbouring farmers' fields flowered between 80 and 95 DAS while the collection of landraces from other districts in northern Nigeria flowered between 55 and 98 DAS when sown at Bagauda (Table 1). Cultivars that 
Table 1. Race (G-C, Guinea caudatum; D-C, Durra caudatum), days 10 flowering, grain colour, 1000 grain mass

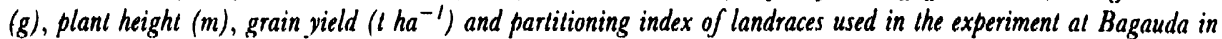
northem Nigeria, 1990

\begin{tabular}{|c|c|c|c|c|c|c|c|}
\hline & Race & $\begin{array}{l}\text { Days to } \\
\text { flower }\end{array}$ & $\begin{array}{l}\text { Grain } \\
\text { colour }\end{array}$ & $\begin{array}{c}\text { Grain } \\
\text { mass }\end{array}$ & $\begin{array}{l}\text { Plant } \\
\text { height }\end{array}$ & $\begin{array}{l}\text { Grain } \\
\text { yicld }\end{array}$ & $\begin{array}{l}\text { Partitioning } \\
\text { index }\end{array}$ \\
\hline Ngeberi Kimi & Gi-C: & 56 & white & 32.0 & 1.97 & 1.6 & 0.74 \\
\hline Niger Early & (G-C: & 56 & white & 32.5 & 2.02 & 1.9 & 0.81 \\
\hline Kola FI-Mota & ( B-C: & 58 & white & 28.0 & 2.14 & 1.7 & 0.70 \\
\hline Yar Gumel & ( $\mathrm{B}-\mathrm{C} i$ & 62 & white: & 39.3 & 2.39 & 2.6 & 0.56 \\
\hline Kura Dandalama & D.C: & 63 & yellow & 42.7 & 2.8 .5 & 2.1 & 0.85 \\
\hline Yar Wuri (S.) & G-C: & 64 & white & 37.0 & 2.46 & 2.2 & 0.75 \\
\hline Yar Washa & G-Ci & 6.5 & white & 41.9 & 2.25 & 2.4 & 0.82 \\
\hline Bagoba Red & G-C & 68 & red & 33.8 & 2.21 & 3.1 & - \\
\hline Jawa Sanda & $\mathrm{G}-\mathrm{C}$ & 73 & white & 34.6 & 2.63 & 2.9 & 0.73 \\
\hline Yar Wuri ((i.) & G-C: & 73 & white & 32.8 & 2.63 & 3.0 & 0.66 \\
\hline Yar Wuri (D.) & ( $-\mathrm{C}$ & 74 & white & 34.6 & 2.43 & 3.1 & - \\
\hline Yar Duwigi & G-C & 7.5 & white & 35.5 & 2.51 & 3.4 & 0.55 \\
\hline Yar Mai Garayc & G-G & 75 & white & 33.4 & 2.71 & 3.2 & 0.68 \\
\hline Gaya Early (K.) & D-C: & 80 & yellow & 29.8 & 3.22 & 3.7 & 0.73 \\
\hline Gaya Farly (B.K.) & $\mathrm{D}-\mathrm{C}$ & 80 & yellow & 3.1 & 3.38 & 2.8 & 0.76 \\
\hline Warwar Bashi (B.) & G-C & 81 & white & 26.3 & 2.92 & 2.2 & - \\
\hline Yar Durmu Uku & G-Ci & 83 & white & 36.6 & 3.21 & 2.0 & - \\
\hline Lafia Danbatta & G.C & 86 & yellow & 26.7 & 2.46 & 2.1 & - \\
\hline Kadawa Farafara & G-C: & 87 & white & 29.1 & 2.95 & 2.7 & - \\
\hline Yar Gadama & G-C & 87 & whitc & 30.7 & 3.28 & 1.7 & - \\
\hline Mori (B.) & D-C: & 89 & ycllow & 38.7 & 3.12 & 1.9 & - \\
\hline Kalwa & G-C & 89 & white & 29.7 & 2.94 & 1.6 & - \\
\hline Kitsen Damo & (B-C & 91 & white & 33.5 & 3.51 & 1.7 & - \\
\hline Yarlan & G-C & 91 & white & 26.8 & 3.61 & 0.8 & - \\
\hline Farafara Binono & G-C & 92 & white & 3.5 .0 & 3.54 & 1.0 & - \\
\hline Yar Iabe & G-C & 92 & white & 33.3 & 2.98 & 1.4 & - \\
\hline Yar Tudu & G-C & 92 & white & 37.5 & 3.30 & 1.8 & - \\
\hline Kiyawa Farafara & G-C: & 93 & white & 32.3 & 3.29 & 2.0 & - \\
\hline KSV 8 & G.C. & 97 & white & 29.4 & 3.02 & 0.9 & - \\
\hline Gezawa White & G-C & 97 & white & 28.0 & 3.24 & 0.0 & - \\
\hline L 187 & G-C & $t$ & white & - & - & - & - \\
\hline L.533 & G.C & $\dagger$ & white & - & - & - & - \\
\hline Yar Zandam & D-C & + & yellow & - & - & - & - \\
\hline Barzaga & G-C & $\dagger$ & white & - & - & - & - \\
\hline Samsorg 16 & G-C & $\dagger$ & white & - & - & - & - \\
\hline Mori Local (S.) & D-C & $\dagger$ & white & - & - & - & - \\
\hline
\end{tabular}

†Did not flower.

flowered later than 98 DAS failed to produce any grain as soil water reserves had been exhausted.

Time to panicle initiation in sorghum cultivars is dependent on temperature and photoperiod, whereas the length of the grain-filling period is dependent mainly on temperature (Hammer et al., 1989). Little information is currently available on the response of Nigerian landraces to these variables. Muchow (1990) found a linear relationship between the inverse of the effective grain-filling period and mean air temperature for sorghum cultivar Dekalb DK55 when sown 


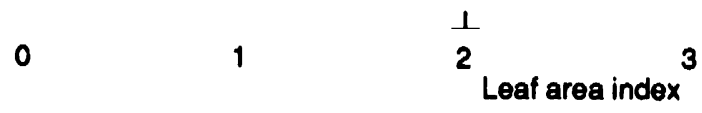

Fig. 2. Relation between the keaf area at flowering and the fraction of light interenphed be landraters flowering less than 80) daỵs afler sowing.

in different seasons in northern Australia. $\Lambda t$ the mean air temperature experienced during grain filling in the current experiment, Dekalb DK 5.5 would fill grain in 26 days. This compares favourably with a mean length of the grain-filling period for landraces at Bagauda of 23.9 \pm 0.6 days. 'The length of the grain-filling period was independent of the time to flowering because of the stable air temperatures during the experiment. Flowering in sorghum marks the end of the period of stem extension. Early flowering lines have fewer internodes to extend and consequently had a final height of about $2 \mathrm{~m}$ compared with $3104 \mathrm{~m}$ in later maturing lines (Table 1). In general, the landraces were about $3.6 \mathrm{~cm}$ taller with each day of delay in flowering.

\section{Leaf area and light interception}

The leaf area index at flowering ranged from 1.2 to 3.8 and was directly proportional to the time to flowering. Leaf areas were measured on selected landraces requiring less than 81 days to flower but not on crops flowering later than 81 DAS as the proportion of dead lower leaves rose sharply after this time. When leaf areas were related to light interception at flowering, a common value of extinction coefficient could be used to describe the data $(K=0.54$, Fig. 2). This extinction coefficient for these West African sorghum landraces was similar to those for landraces from China, Yemen and Sudan (Matthews et al., 1990) and for 

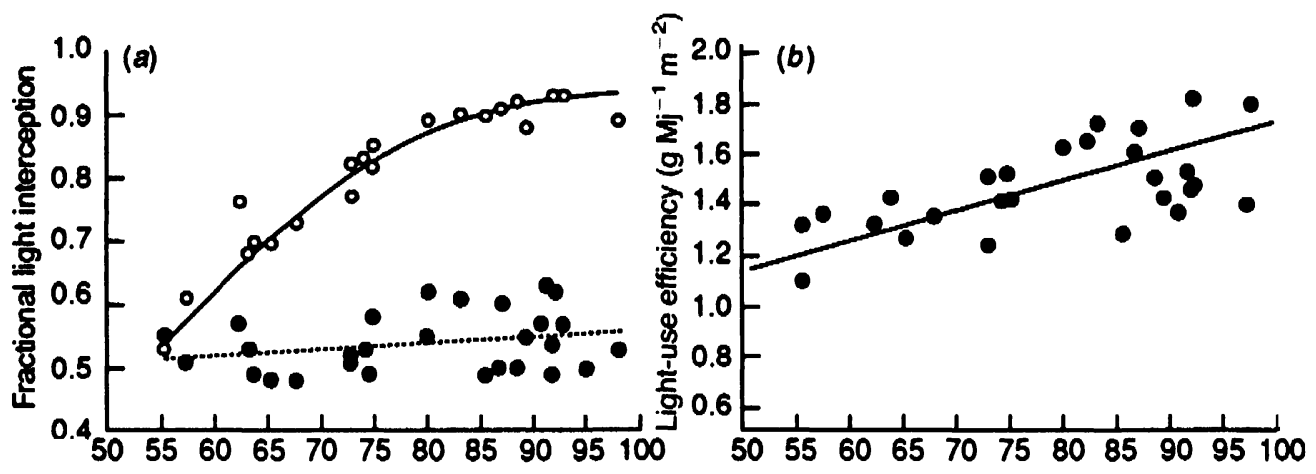

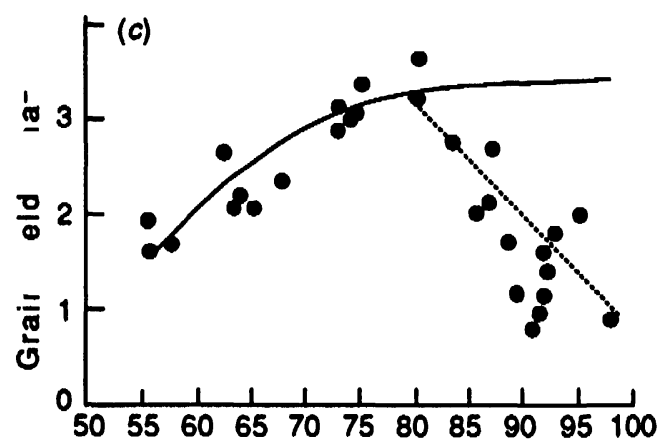

Time to flowering (days) $0.5-(d)$

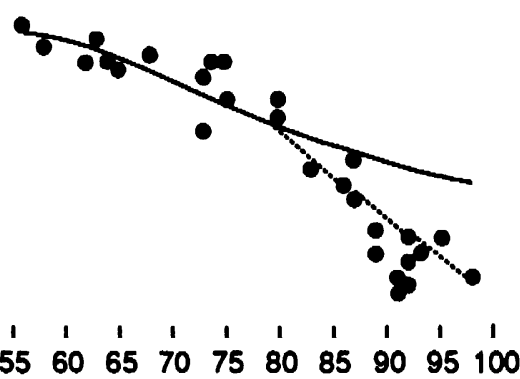

Time to flowering (days)

Fig. 3. Relation between time to flowering and (a) light interception measured 41 days after sowing (I)AS, dotted line) and at flowering (solid linc), (b) light-use efficiency between 41 and 75 DAS, (c) grain yiclds, and (d) harvest indices. The solid line in (a) is estimated from the expolinear equation (Goudriaan and Monteith, 1990) and the dotted linc is a fitted linear regression to the observed data. The solid lines in (c) and (d) are the simulated values in the absence of moisture stress and the corresponding dashed lines are simulated values using the soil water budget as an input. All points are a mean of four replicates.

improved sorghum cultivars, such as ICSP1 (Goudriaan and Monteith, 1990) and Texas 610 (Heslehurst and Wilson, 1986).

All lines intercepted a similar fraction of light $(0.53 \pm 0.06)$ at $41 \mathrm{DAS}$, as no lines had reached the flag-leaf stage by then (Fig. 3a, dashed line). Early maturing lines could not utilize all the incident solar radiation at flowering as early flowering restricted the production of leaves. The fraction of light intercepted at flowering ranged from 0.55 in the early maturing lines to 0.92 in the later maturing lines (Fig. 3a, solid line). There was little increase in light intercepted at flowering by plants that flowered more than 80 DAS despite the production of a greater number of leaves. The line relating light interception to days to flowering was fitted using the formula from which the expolinear equation of Goudriaan and Monteith (1990) was derived.

\section{Radiation-use efficiency}

Muchow and Coates (1986) showed that the radiation-use efficiency (RUE) of grain sorghum under irrigated conditions was stable throughout crop growth. When grown under rainfed conditions at Bagauda, crops with an expanding 
canopy had a mean RUE of $1.45 \mathrm{~g} \mathrm{MJ}^{-1} \mathrm{~m}^{-2}$ (measured from 41 to $75 \mathrm{D}$ ) $\mathrm{AS}$, before'water stress became a constraint to production) and this appeared to be unaffected by the time to flowering, though a lower value, 1.35, was recorded after the landraces had flowered. This result is similar to values measured in other parts of the semi-arid tropics by Muchow and Coates (1986). Natarajan and Willey (1980) and Flower et al. (1990). Muchow and Coates (1986) suggested several reasons why the RUE may decrease after flowering, but the most likely reason in this case is a deterioration of the quality of the canopy due to nutrient stress. Leaf anthracnose (Colletotrichum graminicola) also occurred in some lines during the later stages of grain filling.

\section{Grain yield and harcest index}

Grain yield ranged from 1.8 to $3.6 \mathrm{t} \mathrm{ha}^{-1}$ (Table 1) as a direct result of greater light interception by the later maturing lines. 'The yield potential of carly maturing lines is often not exploited as they do not use resources effectively when planted at a conventional row spacing. Grain yields of landraces such as Ngeberi Kimi, for example, could be expected to double if a narrower row spacing and higher plant population were used. Lines that flowered later than 80 D D AS suflered a reduction in yicld in proportion to the delay in flowering (Fig. 3c) because of the declining soil water status.

The harvest index reached 0.46 in the earliest maturing lines but decreased lincarly as time to flowering increased to 80 days (Fig. 3d). In later flowering lines, the harvest index decreased substantially because of drought stress.

\section{Model description}

A simple growth model was used to explain these differences in yield, the harvest index and dry matter production in a biologically meaninglul way. Prior to flowering, the potential amount of above-ground dry matter produced each day $\left(\mathrm{DM}_{\mathrm{i}}\right)$ was calculated as a product of four variables:

$$
\mathrm{DM}_{\mathrm{i}}=Q_{\mathrm{i}} \times f \times \varepsilon_{\mathrm{s}} \times \rho
$$

where $Q_{i}$ is the amount of short wave radiation incident on the crop $\left(\mathrm{MJ} \mathrm{m} \mathrm{m}^{-2}\right)$, $f$ is the fraction of this radiation intercepted by the crop (estimated as mentioned above), $\varepsilon_{\mathrm{s}}$ is the RUE (set at $1.4 \mathrm{~g} \mathrm{MJ}^{-1} \mathrm{~m}^{-2}$ ) and $\rho$ is the partitioning index with a value of 1 . These variables were also calculated after flowering although assimilate was then being used to produce grain. It was assumed there was no decrease in $f$ or $\varepsilon_{\mathrm{s}}$ during the grain-filling period if the conditions were favourable for sorghum (Muchow and Coates, 1986). The thermal time to flowering was calculated and the duration of the grain-filling period set at 411 degree days. In the absence of water stress and with the plant density and arrangement used in this experiment, the potential grain yield of the early maturing lines, such as Niger Early and Kola El-Mota, was $3.8 \mathrm{t} \mathrm{ha}^{-1}$, increasing in later maturing lines to $6.4 \mathrm{t}$ $\mathrm{ha}^{-1}$. Discrepancies between estimated potential and observed grain yields could 
be partly explained when actual values of the partitioning index $\rho$ were used. This was estimated as the ratio of dry grain weight to the gain in above-ground dry matter during grain-filling and had a mean value of 0.71 , which was independent of time to flowering (Table 1). In contrast, Herbert et al. (1986) found that $\rho$ ranged from 0.87 to 1.26 (mean 1.02) in hybrids that flowered in 57-64 $\mathrm{D} \Lambda \mathrm{S}$. They suggested that these high values of $\rho$ contributed to the high grain yields $(8.2$ $\mathrm{t} \mathrm{ha}^{-1}$ ) and harvest indices (0.52) which they observed, pointing out that values of $\rho$ greater than 1 arise from the mobilization of stem reserves during grain filling. Increasing the value of $\rho$ from 0.71 to 1.10 would increase the yields of landraces, such as Gaya Early, from 3.4 to $5.3 \mathrm{tha}^{-1}$ and grain yields of this size have been recorded in advanced hybrid yicld trials planted in neighbouring ficlds (ICIRISAT, 1990). 'These hybrids were planted at a higher population of 10.8 plants $\mathrm{m}^{-2}$ and had a mean time to flowering of 64 days.

$\Lambda$ decrease in light interception of about $20 \%$ was observed during the grainfilling period in a subsequent experiment with landraces (D. J. Flower, unpublished). A model using the average value of $\rho(0.71)$, and a $20 \%$ decrease in light interception during the grain-filling period gave close agreement between observed and calculated values of grain yield for lines flowering within 80 DAS, though later flowering lines suffered from moisture stress (Fig. 3c). The RUE of sorghum, as with other crops, decreases under moisture stress conditions (Flower et al., 1990). Good agreement between observed and fitted data of grain yields was also found by Sinclair and Ludlow (1986) when RUE was held constant until extractable soil moisture contents were less than $30 \%$, and then reduced in proportion to remaining extractable soil moisture and the transpiration rate.

As with grain yield, there was close agreement between the calculated and observed harvest indices for landraces which flowered within 80 DAS; thereafter, water stress reduced harvest indices. The extent of the reduction could be estimated if the effect of water stress on RUE was taken into account. It was not found necessary to alter the value of $\rho$ or $f$ as pronounced wilting was not observed.

\section{Regional agronomic implications}

The results from Bagauda in 1990 are supported by the KNARDA trial results in 1986, especially those from the nearby village of Kadawa. The shape of the relation between time to flowering and grain yield was similar at both sites, with the lines that flowered in 80 days giving the highest yields (Figs $3 \mathrm{c}$ and 4 ). The larger grain yiclds of short duration lines at Bagauda were a direct consequence of a higher plant density and fertilizer level.

Similar results were obtained at Katsina, Mallamadori and Kaffin Maiyaki (KNARDA, 1986). These locations are within $150 \mathrm{~km}$ of Bagauda but received different amounts of rainfall, though solar radiation, temperature, humidity and evaporation rates were similar. The soils at Katsina (90 cm in depth) and Mallamadori (more than $150 \mathrm{~cm}$ in depth) are Entisols with a water holding capacity of about 125-160 mm (Payne et al., 1991). 

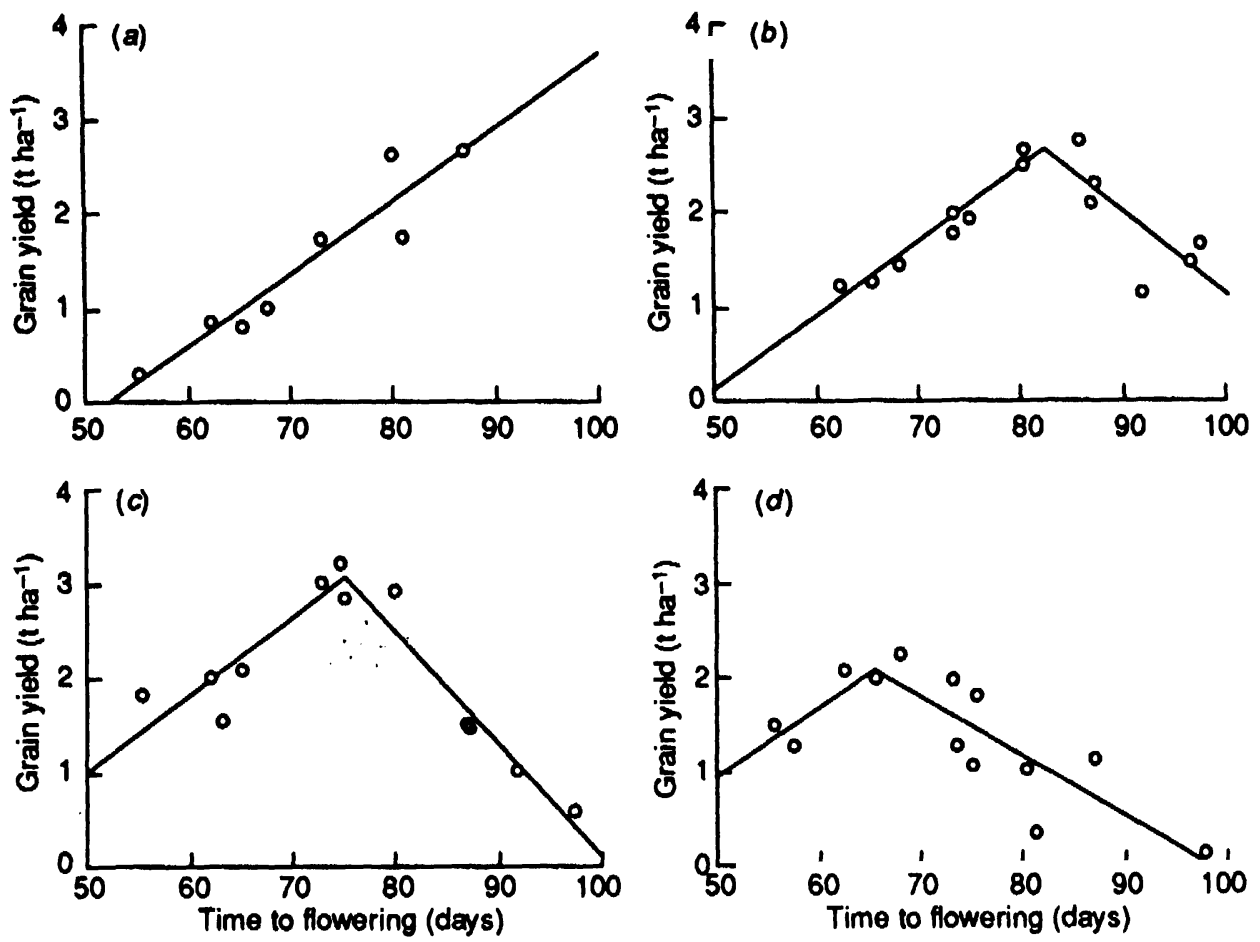

Fig. 4. Relation between grain vields and time to flewering at (a) Kallin Mativaki, 751 mm rainlill. (b) Kadawa, $700 \mathrm{~mm}$. (c) Katsina, $500 \mathrm{~mm}$, and (d) Mallannadori, 336 mm, in 19886 .

Grain yiclds from all these trials were highly site-specilic with a large genotype $x$ environment interaction. The order of flowering was maintained across site's over this small range of latitudes and planting dates (KN $\Lambda \mathrm{RI} \Lambda$, unpublished data). Maximum grain yields varied from $2.25 \mathrm{t} \mathrm{ha}^{-1}$ at Mallamadori $10.3 .2 \mathrm{t}$ $\mathrm{ha}^{-1}$ at Katsina (Fig. 4). Because of the low plant population, 5 plants $\mathrm{m}^{-2}$, (aarly maturing material did not yield more than 2.2 t ha ${ }^{-1}$ at any of the locations. The time to flowering depended primarily on the length of the rainy period and the amount of rain received and was greatest at Kalfin Maiyaki and least at Mallamadori. Despite these differences, the similarity of the relation between grain yield and time to flowering at all the sites suggests that the data from Bagauda, if correctly interpreted, can have relevance throughout the region. These data also highlight the importance of the soil water balance and the length of the growing period as major determinants of production in the region.

\section{Potential for improved productivity}

The productivity of sorghum-based systems may be improved if the biological, physical and socio-cconomic constraints to production of the present cropping systems in the region can be identified. To explore the opportunities for sustainable increases in production it will be necessary to describe the features of the sorghum landraces. Although a broad spectrum of landraces is available in the Sudano-Sahelian region, their possible adaptation requires knowledge of their 
thermal time to flowering (a function of response to daylength) and partitioning indices, since many of their other attributes are relatively stable. These include thermal time for the duration of grain filling, light-cxtinction coefficient and lightuse efficiency. With good management, selected landraces from the region can yield more than $3.5 \mathrm{t} \mathrm{ha}^{-1}$. This study has shown that there is variability in the partitioning index among the landraces and that it is well below that measured in hybrids. Direct selection for $\rho$ would thus be one way to increase yields in the region in a manner acceptable to farmers. This need not be at the expense of fodder production if the amount of 'lost time' can be reduced. As cultivars with a range of flowering dates, but similar physiological attributes, are available, farmers can select those best adapted to the length of the growing season in their locality.

Acknowledgements. 'The study was supported by ICRISAT (West African Sorghum Improvement Program) Nigeria, and a grant from the Italian government. The study was made possible by the competent technical assistance of A. Ekeke, A. Sodangi, I. Danja and I. Shaibu. This paper is dedicated to the endurance of my wife K. M. Greer-Flower.

\section{REFERENGES}

Carr, S. J. (1989). Technology for small-scale farmers in sub-Saharan Africa. World Bank Technical Paper 109.

Ciurtis, D. I. (1967). The races of sorghum in Nigeria: their distribution and relative importance. Experimental Agriculture 3:275-286.

Curtis, D. I. (1968). The relation between the date of heading of Nigerian sorghum and the duration of the growing season. Experimental Agricullure 4:215-22.5.

FAO (1993). 1993 FAO Production Yearbonk 44:8.5. Rome: FAO.

Flower, D. J., Peacock, J. M. \& Usha Rani, A. (1990). Influence of osmotic adjustment on growth, stomatal conductance and light interception of contrasting sorghum lines in a harsh environment. Atustralian Journal of Plant Physiology' 17:91-105.

Goudriaan, J. \& Montcith, J. L. (1990). A mathematical function for crop growth based on light interception and leaf area expansion. Annals of Botany 66:695-701.

Hammer, G. L., Vanderlip, R. L., Gilson, G., Wade, L. J., Henzell, R. G., Younger, D. R., Warren, J. \& Dale, A. B. (1989). Genotype-by-environment interaction in grain sorghum. II. Effects of temperature and photoperiod on ontogeny. Crop Science 29:376-384.

Herbert, S. W., Fukai, S., Scarle, C., Maharjan, B. B. \& Hermus, R. C. (1986). Variation in grain yield among sorghum hybrids sown in spring and summer. Proceedings of the 1st. Australian Sorghum Conference, Queensland Agricultural College, Lawes, Australia, t-6 February, 1986. Lawes, Australia: Queensland Agricultural Collcge.

Heslchurst, M. R. \& W'ilson, G. L. (1986). The influence of plant population on canopy structure, grain yield and yield components for a range of cultivars. Proceedings of the 1st. Australian Sorghum Conference, Queensland Agricultural College, Lawes, Australia, to Februan', 1986. Lawes, Australia: Qucensland Agricultural Collcge.

ICRISAT (1990). ICRISAT West African Programs Annual Report 1989. Niamey, Niger: ICRISAT Sahelian Cienter.

IAR (1988). Detailed Soil and Vegetational Surveys of Proposed Research Farms at Bagauda and Kadawa, Kano Statc. Zaria, Nigeria: Institutc for Agricultural Research.

KNARDA (1986). Agricultural Adaptive Research in 1986: Rainfed. Kano, Nigeria: Kano State Agricultural and Rural Development Authority. 
Kowal, J. M. \& Knabe, D. T. (1973). An Agrodimalological Allas of the Northern Stales of Nigeria. Zaria. Nigeria: Ahmadu Bello University Press.

Matthews, R. B., Azam Ali, S. N. \& Peacock, J. M. (1990). Response of four sorghum line's Io mid-season drought. 11. Leaf characteristics. Field Crops Research 25:297-308.

Mengesha, M., Appa Rao, S. \& Prasada Rao, K. E. (1991). Germplasm resources for the improvement of sorghum and millet in sub-Saharan Africa. SAF(iRAD). Inter-netucork (ionference on Food (irain Improbement, Niamey, Niger, \&-14 March, 1991.

Muchow, R. C. (1990). The effect of high temperature on the rate and duration of grain growth in fieldgrown Sorghum bicolor (L.) Monech. Australian Joumal Agriculiural Resentch $\$ 1: 329-333$.

Muchow, R. C. \& Coates, D. B. (1986). An analysis of the environmental limitation to yield of irrigited grain sorghum during the dry season in tropical Australia using a radiation interception medel. Australian Journal Agricultural Research 37:135-1.48.

Natarajan, M. \& Willey, R. W. (1980). Sorghum-pigeon pea intercropping and the eflects of plant population density. 2. Resource use. Journal of Agricultural Science 95:59-6.5.

Payne, W' A., Lascano, R. J. \& Wendt, C. W. (1991). Annual soil water balance of cropped and fallowed millet ficlds in Niger. In. Soil Water Balance in the Sudano-Sahelian Zone (Proceedings of an International Workshop, Niamey, Niger, Fetruary 1991) IAHS P'ublication 199. W'allingford. UK: IAHS Press, Institute of Hydrology.

Prasada Rao, K. E.. Obilana, A. T. \& Mengesha, M. H. (1985). Collection of kaura, farafiara and guineense sorghum in northern Nigeria. Journal d Agriculture Traditionelle et de Botanique Appliquee 32:73-81.

Sinclair, T. R. \& Ludlow, M. M. (1986). Influence of soil water supply on water less of four tropical grain legumes. Australian Journal of Plant Physiology 13:329-341.

Squire, G. R. (1990). The Physiology of Tropical Crop Production. Wallingliord, UK: (AAB International.

van Donk, S. J., Sivakumar, M. V. K. \& Kanemasu, E. T. (1988). Estimation of Penman Potential Evaporation for the West African Sahel with an IBM PC. Agricultural Experimental Station, Kansas State University Department Report. Manhattan, Kansas, USA: Kansas State Iniversity. 